\title{
TEENAGE BREAST MALIGNANCY WITH RARE HISTOPATHOLOGY
}

Arunima Mukhopadhyay, Sukla Naskar, Nidhi Rai, Sumit Nandy, Keya Basu.

1. Assistant Professor. Department of General Surgery,Calcutta National Medical College, Kolkata.

2. Assistant Professor. Department of Pathology, Calcutta National Medical College, Kolkata.

3. Assistant Professor. Department of Pathology, Calcutta National Medical College, Kolkata.

4. Demonstrator. Department of Pathology, Calcutta National Medical College, Kolkata.

5. Professor. Department of Pathology, Calcutta National Medical College, Kolkata.

\section{CORRESPONDING AUTHOR}

Dr. Arunima Mukhopadhyay,

836 block -p , New Alipore ,

Kolkata - 700053.

E-mail: ram_arunima@yahoo.co.in

Ph: 00919830166404,00913324003998

ABSTRACT: Breast carcinoma is rare in teenagers. Among the histological variants of breast carcinoma, papillary carcinoma has an incidence of only $0.5 \%-1 \%$. Papillary carcinoma usually affects postmenopausal women. Here we are reporting a rare presentation of papillary carcinoma of the breast in a young woman of seventeen years of age.

KEYWORDS: Breast carcinoma in teenager, Papillary carcinoma of breast, young woman with papillary carcinoma of breast.

INTRODUCTION: Carcinoma of the breast is extremely rare below the age of 20 years [1]. It is a disease primarily of older women, with $75 \%$ of cases occurring in women over 50 years of age[2]. Current terminology describes histology of breast carcinoma based on the dominant cytoarchitecture of the lesion and one of the invasive ductal carcinoma variants is described as the papillary variety.

Papillary carcinoma accounts for less than $2 \%$ of all breast carcinomas, generally presenting in the seventh decade. Typically papillary cancer is small ( $2-3 \mathrm{~cm}$ in diameter) with axillary metastasis in one third of patients. Papillary carcinoma is an indolent, slowly progressive disease $[1,2]$.

CASE REPORT: A seventeen year old girl married for one year, presented with a painless progressively increasing lump in her left breast noticed since last six months. On examination, the lump was solid, well circumscribed, $5 \mathrm{~cm}$ in diameter in the superolateral quadrant of the left breast, fixed to the breast tissue but not fixed to the skin and underlying structures. There was no nipple discharge. There was a mobile left anterior axillary lymph node of $2 \mathrm{~cm}$ in diameter. The other breast and axilla were normal. There was no family history of breast malignancy. She had attained menarche at 12 years of age and had regular menstrual cycles. Fine needle aspiration cytology gave a diagnosis of 'suspicious of malignancy'. Therefore wide local excision of the lump was performed along with excision of the axillary lymph node.

On gross examination, the pathological specimen consisted of two gray brown masses, the larger one from the breast-8X6X2cm and the smaller lymph node- $3 \mathrm{X} 2 \mathrm{~cm}$.Cut section of the large mass revealed an ill-defined gray white area which measured $6 \mathrm{X} 2 \mathrm{~cm}$ with intervening areas of necrosis(Figure 1). On microscopy, multiple sections from the gray white tumor area 
showed neoplastic, hyperchromatic cells arranged in papillary architecture with central fibrovascular core, invading the adjacent stroma. Individual cells were uniform sized with eosinophilic cytoplasm, high nucleocytoplasmic ratio and increased mitotic activity (Figure 2). The lymph node showed reactive hyperplasia. Immunohistochemistry results showed, ER:negative (Figure 3) , PR:negative and Her2/neu negative.

DISCUSSION: Breast cancer is the leading cause of cancer deaths among women with ages 1554 years. Breast cancer in young women below 40 years of age has a very low incidence. The chances of a women getting breast cancer in her thirties is one in 250, in her twenties it is one in 2000 . Available data shows that $75 \%$ of breast tumors occur in women of age $>50$ years, only $6.5 \%$ in women of age $<40$ years and a mere $0.6 \%$ in women of age $<30$ years[2].

In Indian scenario, the average age of breast carcinoma patients is 50-53 years in various population based studies [3]. Though the proportion of Indian breast cancer patients younger than 35 years of age varies from $11 \%$ to $26 \%$, incidence of teenage breast malignancy is almost negligible. [4,5]

The most common histomorphological types is invasive ductal carcinoma not otherwise specified (88\%). Papillary carcinoma in women aged under 35 years is very rare, because it is usually found in post menopausal women [6].

Estrogen(ER) and Progesterone (PR) receptors are found positive in 30-45\% of Indian patients. Carcinomas under 30 years of age have a low incidence of receptor positivity[7], this is corroborative with our case.

Diagnosis of breast carcinoma in young women is more difficult because their breast tissue is nodular, and denser. In early stages, carcinoma can be similar in appearance to more commonly occurring fibroadenomas and fibrocystic disease. Mammography and USG have lower accuracy $[8,9,10]$.

Breast carcinomas of young girls are poorly differentiated with high proliferation rates, receptor negativity and lymphovascular invasion. They are associated with an overall poor prognosis related to survival and relapse $[11,12,13]$.

CONCLUSION: The rarity of malignancy in very young women should not prevent clinician from adequate evaluation of every breast lump. Special emphasis has to be given on tissue diagnosis to exclude malignancy in every case. Papillary carcinoma though mostly occurring in postmenopausal women may also occur in teenagers.

\section{REFERENCES:}

1. Sainsbury R. The Breast In: Bailey\&Love's Short Practice of Surgery, 25th Edition, Edward Arnold, London 2008:827-848.

2. Hankey BF,Miller B,Curtis R, Kosary C; Trends in breast cancer in younger women in contrast to older women. J Natl Cancer Inst Monogr.1994;16:7-14.

3. National Cancer Registry Programme, Consolidated report of the population based cancer registries 1990-1996. New Delhi; Indian Council of Medical Research; 2001.

4. Dinshaw KA, Sarin R, Budrukkar AN, Shrivastava SK, Deshpande DD, Chinoy RF,Badive R,Hawalder R. Safety and feasibility of breast conserving therapy in Indian women; two decades of experience at Tata Memorial Hospital.J Surg Oncol.2006;94:105-13.

5. Agarwal G, Pradeep PV, Aggarwal V, Yip CH, Cheung PS.Spectrum of breast cancer in Asian women.World J Surg.2007:31:1031-40. 
6. Saxena S, Rekhi B, Bansal A, Bagga A, Chintamani, Murthy NS. Clinicomorphological patterns of breast cancer including family history in a New Delhi hospital, India-a cross sectional study. World J Surg Oncol.2005;3:67.

7. Desai SB, Moonim MT,Gill AK,Punia RS,Naresh KN,Chinoy RF. Hormone receptor status of breast cancer in India: a study of 798 tumors. Breast 2000;9:267-70.

8. R.A. Walker, Elees, M B Webb, \& S.J Dearing. Breast carcinomas occurring in young women(<35 years) are different. Br J Cancer 1996 December;74(11):1796-1800.

9. Simmons PS, Jayasinghe YL, Wold LE, Melton LJ $3^{\text {rd }}$. Breast carcinoma in young women. Obstet Gynecol,2011;118(3):529-536.

10. Gajdos C, Tartter PI, Bleiweiss IJ et al. Stage 0 to StageIII breast cancer in young women. J Am Coll Surg 2000;190:523-529.

11. David Mintzer, John Glassburn, Bernard A .Mason and Dahlia Sataloff. Breast cancer in the very young patient:A multidisciplinary case presentation. The Oncologist. December 2002 vol 7.No 6.547-554.

12. Emin Yildirim MD,Tahsin Dalgic MD, Ugur Berberoglu MD. Prognostic significance of young age in breast cancer. J. Surg Oncol .2000;74:267-272.

13. Agrup M,Stal O, Olsen K,Wingren S.C-erbB-2 overexpression and survival in early onset breast cancer. Breast Cancer Res Treat.2000;63:23-29.

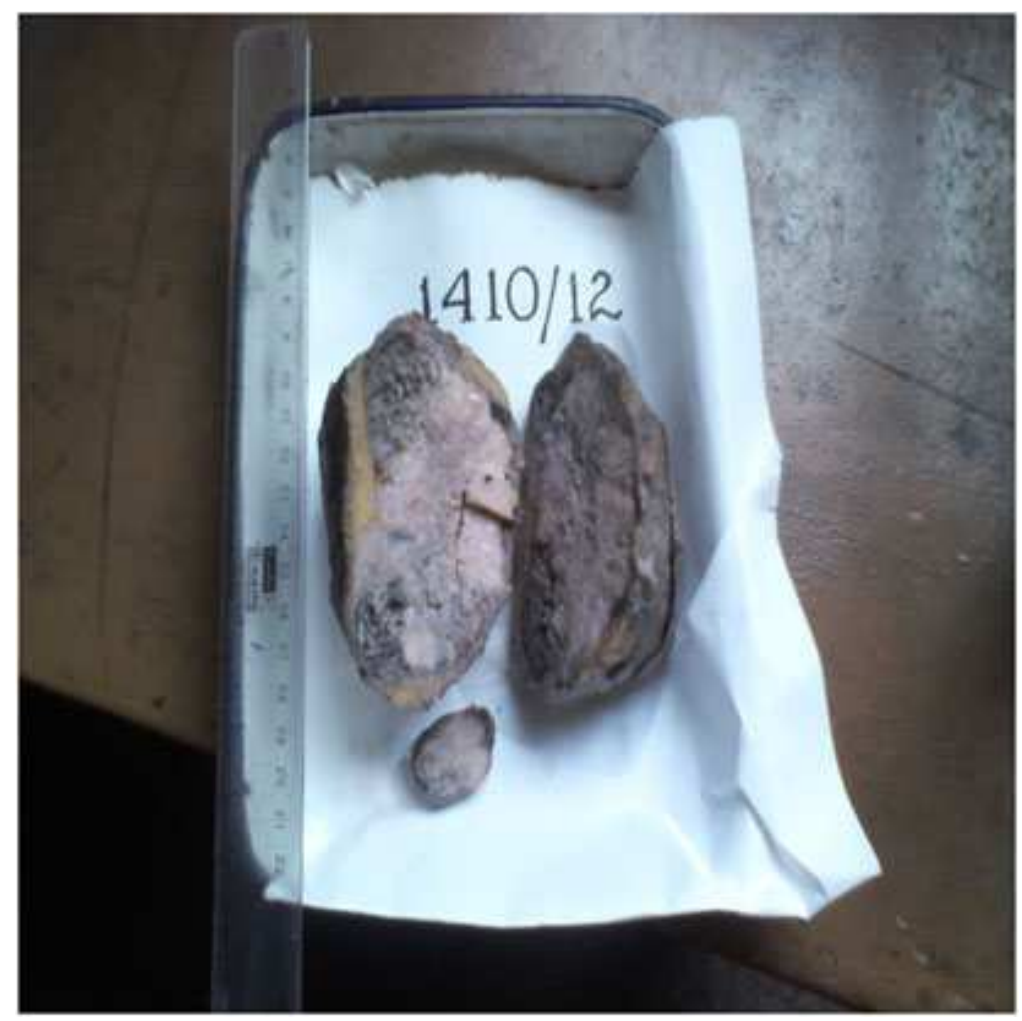

Figure 1: Gross specimen consisting of breast lump $(8 \times 6 \times 2 \mathrm{~cm})$ divided into two halves, cut section showing an illdefined gray- white area $(6 \times 2 \mathrm{~cm})$ of malignancy. The smaller mass is the axillary lymph node $(3 \times 2 \mathrm{~cm})$. 


\section{CASE REPORT}

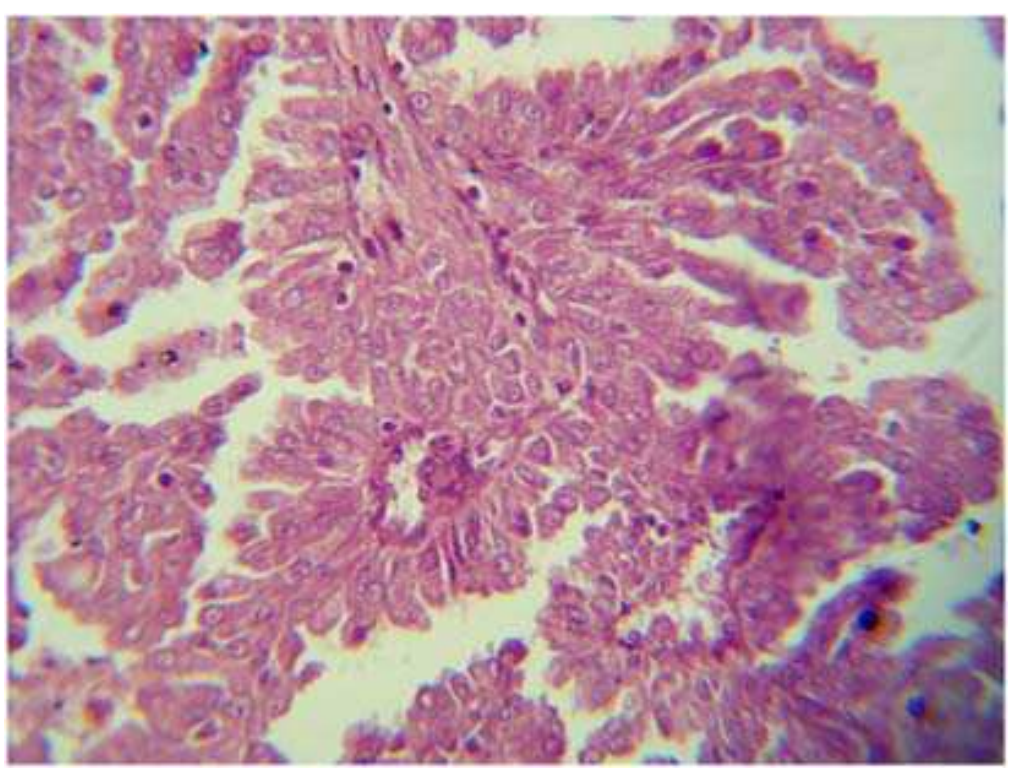

Figure 2: Shows neoplastic cells arranged in papillary architecture with fibrovascular core Nuclei of cells shows hyperchromasia, cytoplasmic eosinophilia and increased mitotic acivity (H/E stain, 40X), thin arrow shows mitotic activity,thick arrow shows nuclear hyperchromasia.

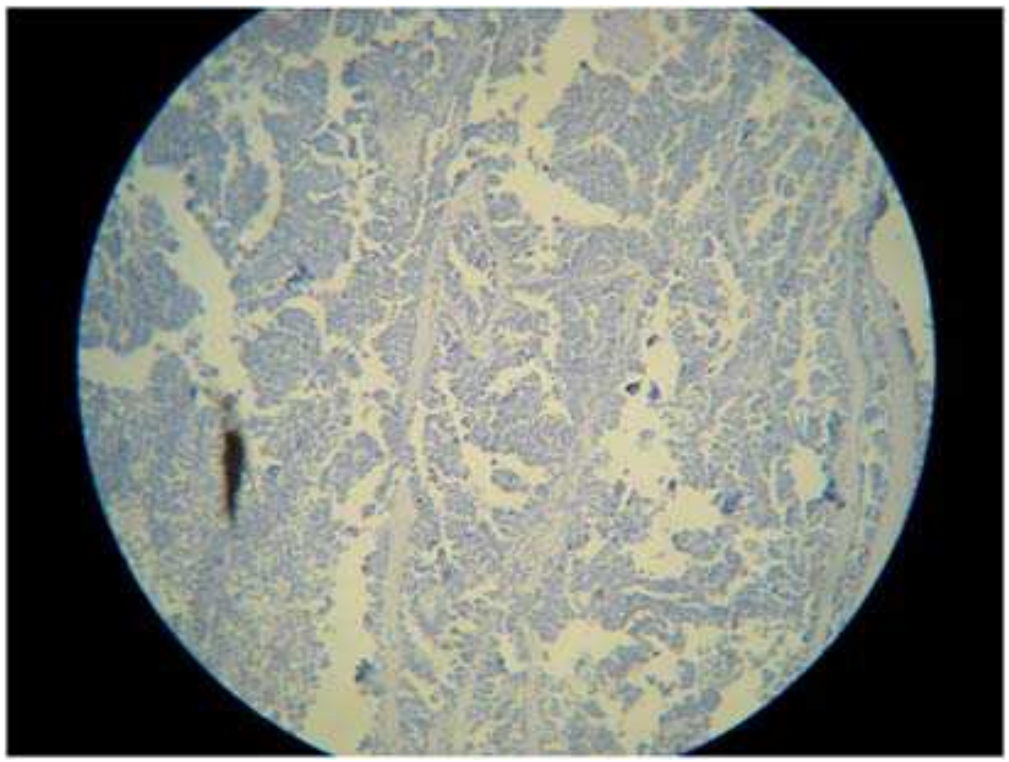

Figure 3: Immunohistochemistry of ER shows negative(Allred score 0/8 ). 